\title{
The Effect of Different Food Types and Rations on the Liver and Muscle of Cod (Gadus morhua $\mathbf{L}$.)
}

\author{
By K. Buchmann and T. Børresen
}

\begin{abstract}
Buchmann, K. and T. Børresen: The effect of different food typers and rations on the liver and muscle of cod (Gadus morhua L.). Acta vet. scand. 1988, 29, 57-59. In a short time feeding experiment it was shown that the liver weight of cod was significantly reduced in prawn-fed cod compared to sand-eel-fed cod. The dry weight and the protein content of the muscle were not significantly reduced. It is concluded that short time energy deprivation of cod primarily affects the liver. The results futher support the view that the food type and ration of cod can produce anomalous effects in field studies of e.g. parasite induced liver weight decrease in cod.
\end{abstract}

liver index; condition factor; protein content of cod muscle.

\section{Introduction}

The main fat and energy store in cod (Gadus morhua L.) is the liver, and deprivation of energy in cod is primarily affecting the liver (Eliassen \& Vahl 1982).

Buchmann (1986) eclucidated the association between acanthocephalan parasite load and liver weight of Baltic cod, and it was suggested that variations of the previous energy intake of cod could produce an anomalous effect in such parasitological field studies.

Thus food preference of cod for e.g. crustaceans could result in a lowered liver weight compared to cod preferentially eating fat fish.

The present work elucidates to what extent the liver weight is affected when cod are fed a low energy diet (crustaceans) compared to cod fed a high energy diet (sand-eels), when the wet weight of the food intake is the same in the two groups.
Additionally it is shown how the weight and protein content of the cod muscle is affected by the food intake.

\section{Materials and methods}

Two groups of immature cod (Gadus morhua L.) of age 2 (otolith-recordings) with a total body length of $36-50 \mathrm{~cm}$ (data for the cod in Table 1) were held in a $10 \mathrm{~m}^{3}$ fish tank for 30 days. The groups were separated by a tightly fitting net (mesh size $25 \mathrm{~mm}$ ), which divided the tank in two equal parts. The salinity of the water was $32.5 \%$ and the temperature $12-15^{\circ} \mathrm{C}$ with an oxygen content of 5.8-6.1 mg/1. The water exchange was 2.9$3.1 \mathrm{~m}^{3} / \mathrm{h}$.

One group of cod was only fed prawns (Pandalus borealis) ( $30 \mathrm{~g}$ wet weight per fish per day) and the other group was fed sand-eels (Ammodytes lancea) (30 g wet weight per fish per day).

Dry weight was determined after drying 
over-night in an oven set at $105^{\circ} \mathrm{C}$, and ash content after further drying at $600^{\circ} \mathrm{C}$ for 24 h. Lipids determined according to the method of Bligh \& Dyer (1959), and protein determined according to the Kjeldahl method. Carbohydrate was estimated by subtraction. Energy content estimates were based on general calorimetric values for each of the constituent components.

The food was frozen $\left(-30^{\circ} \mathrm{C}\right)$ but thawed before feeding.

At the end of the experiment the cod were slaughtered and their total body length recorded. The sex, the gutted weight and the liver weight were recorded whereafter the liver index: $\frac{\text { Liver weight }(\mathrm{g}) \times 10^{4}}{\text { (body length }(\mathrm{cm}))^{3}}$ and the conditionfactor: $\frac{\text { gutted weight }(\mathrm{g}) \times 10^{2}}{(\text { body length }(\mathrm{cm}))^{3}}$ were calculated.

The dry weight and the protein content of the cod muscle from some of the cod were determined by the methods described above. The Mann-Whitney U-test was employed to detect differences of means.

\section{Results}

It is shown (Table 2) that although the two groups of cod received the same wet weight of food the energy content of the crustacean food is markedly lowered in relation to the sand-eel food. This is due to the low fat content and dry weight of the crustaceans.

No sex difference in any of the recorded parameters was found. It was shown (Table 1) that only the liver weight and thus also the liver index were significantly reduced $(P$ $<0.01$ ) in prawn-fed cod relative to the sand-eel-fed cod.

The low energy intake in prawn-fed cod resulted only in an insignificantly reduced gutted weight and protein content of the muscle (Table 1). Neither was the dry weight of the muscle significantly different in the two groups (Table 1).

There was no difference in body length between the groups and the sex ratios were about equal ( 0.8 in prawn-fed cod and 0.9 in sand-eel-fed cod (female to male ratio)).

Table 1. Data for cod in the experimental groups.

\begin{tabular}{|c|c|c|c|c|c|c|}
\hline & \multicolumn{3}{|c|}{ Sand-eel-fed cod } & \multicolumn{3}{|c|}{ Prawn-fed cod } \\
\hline & $\mathrm{n}$ & $\overline{\mathbf{x}}$ & S.D. & $\mathrm{n}$ & $\overline{\mathbf{x}}$ & S.D. \\
\hline Total body length $(\mathrm{cm})$ & 19 & 43.1 & 3.1 & 18 & 42.7 & 3.1 \\
\hline Gutted weight (g) & 19 & 776.2 & 193.7 & 18 & 730.6 & 164.2 \\
\hline Liver weight (g) & 19 & 57.0 & 23.9 & 18 & 27.9 & $8.5^{* *}$ \\
\hline Dry weight of muscle $\%$ & 12 & 81.3 & 0.5 & 10 & 81.4 & 0.5 \\
\hline Protein of muscle $\%$ & 10 & 17.97 & 0.40 & 10 & 17.67 & 0.53 \\
\hline Condition factor & 19 & 0.95 & 0.05 & 18 & 0.93 & 0.05 \\
\hline Liver index & 19 & 6.77 & 1.74 & 18 & 3.54 & $0.84^{* *}$ \\
\hline
\end{tabular}

**: $\mathrm{P}<0.01$ 
Table 2. Composition of the food types.

\begin{tabular}{lcc}
\hline Food type & $\begin{array}{l}P \text {. borealis } \\
\text { (prawns) }\end{array}$ & $\begin{array}{l}\text { A. lancea } \\
\text { (sand-eels) }\end{array}$ \\
\hline Dry weight \% & 20 & 26 \\
Ash \% & 3.2 & 2.8 \\
Lipids \% & 1 & 11 \\
Protein \% & 14 & 12 \\
Carbohydrate \% & 1.8 & 0.2 \\
Estimiated energy content & 97 & 172 \\
(kcal per 100 g wet W.) & & \\
\hline
\end{tabular}

\section{Discussion}

This short time experiment clearly demonstrates that the liver weight is primarily affected during energy deprivation of cod. This is in accordance with Eliassen \& Vahl (1982), who mentioned that cod muscle only contributed 4-5\% of the total energy decrease when energy balance was negative. Also Love (1970) stated that during energy deprivation lipid depots of fish exert a sparing effect on protein catabolism. Danulat (1986) found that the lipid content of the liver from cod fed crustaceans was markedly lower compared to the liver lipid content of fishfed cod, whereas the condition factor was only weakly reduced.

These results are in accordance with the present investigation, which showed that the protein content of the muscle was only insignificantly lowered during the relative starvation of prawn-fed cod.

Our results support the view of Buchmann (1986) that differences in food type and energy intake of cod can produce anomalous effects in field studies, in which the associa- tion between parasitism and liver weight of cod is studied.

\section{Acknowledgements}

We thank Mr. Niels Alsted at the Technological Laboratory's division in the North Sea Centre in Hirshals, Denmark, for setting up the fish tank facilities and for conducting the feeding of the fish. Thanks also to the technical staff at the same division in Hirtshals for skilful technical assistance with the chemical analyses. The research was supported by The Council of Technology, Grant 1983-133/001-83.399.

\section{References}

Bligh E G, Dyer $W$ G: A rapid method of total lipid extraction and purification. Can. J. Biochem. Physiol. 1959, 37, 911-917.

Buchmann K: On the infection of Baltic cod (Gadus morhua L.) by the acanthocephalan Echinorhynchus gadi (Zoega) Müller. Nord. Vet.-Med. 1986, 38, 308-314.

Danulat $E$ : The effects of various diets on chitinase and $\beta$-glucosidase activities and the condition of cod, Gadus morhua (L.). J. Fish Biol. 1986, 28, 191-197.

Eliassen J E, Vahl O: Seasonal variations in the biochemical composition and energy content of liver, gonad and muscle of mature and immature cod, Gadus morhua (L.) from Balsfjorden, northern Norway. J. Fish Biol. 1982, 20, 707-716.

Love R M: The chemical biology of fishes. Academic Press, London \& New York, 1970.

\begin{abstract}
Sammendrag
Fodertypens betydning for torskens lever og muskel. I et kort-tids fodringsforsøg påvistes at levervægten hos torsk reduceredes signifikant hos rejefodrede torsk sammenlignet med torsk fodret med fed fisk. Proteinindhold i muskel og vægten af renset fisk reduceredes derimod kun ubetydeligt.
\end{abstract}

(Received August 25, 1987).

Reprints may be requested from: K. Buchmann, Department of Hygiene and Microbiology, Royal Veterinary and Agricultural University, 13 Bülowsvej, DK-1870 Frederiksberg C, Denmark. 
